\title{
Review on Factors Affecting Youth Participation in Agribusiness in Ethiopia
}

\author{
Taddesse Moreda \\ Department of Agricultural Economics, College of Agriculture and Natural Resource, Mekdela Amba University, Tulu Awuliya, Ethiopia
}

Email address:

taddessemoreda@gmail.com

\section{To cite this article:}

Taddesse Moreda. Review on Factors Affecting Youth Participation in Agribusiness in Ethiopia. Plant. Vol. 8, No. 4, 2020 , pp. 80-86. doi: $10.11648 /$ j.plant.20200803.15

Received: September 1, 2020; Accepted: November 11, 2020; Published: November 23, 2020

\begin{abstract}
Ethiopian agriculture is the largest sector which is approximately employing 85\% of the country's population. Out of labor forces working in agriculture in Ethiopia, young people share about 50 percent. This review has addressed three specific objectives (assessing contributions of agribusiness in creating employment opportunity for youth, identifying factors affecting youth participation in agri-business and assessing types of agribusiness in Ethiopia). Agriculture which includes crop production, animal husbandry, forestry, fisheries and apiculture remains by far the most important sector of the Ethiopia from which livestock constitute the largest component of the country's agricultural sector. Despite agribusiness plays great role in employing people, youth are challenged by many problems in agribusiness. Limited access to land, inadequate access to financial services, gender or sex, backwardness of agricultural tools, and attitudinal problems are some of the challenges for youth involvement and advancement in agribusiness. Therefore, providing improved credit system, equally distributing available land and aiding youth to conserve soil, improving extension system through providing incentives to participants and creating more awareness in changing attitudes of community and youth toward agriculture, providing gender awareness, introducing good varieties and animal species and introducing new technological tools are recommended to accelerate their participation and success in agribusiness.
\end{abstract}

Keywords: Youth, Participation, Challenges, Agribusiness, Ethiopia

\section{Introduction}

\subsection{Background of the Review}

Agriculture plays important role by absorbing large people across the world. Globally, it accounts for $32 \%$ of total employment [31]. For Africans living in rural areas, agriculture remains the single largest source of employment and income [49]. It constitutes considerable potential to provide gainful employment opportunities to a large number of youth in Africa [33]. Agribusiness presents tremendous opportunities for economic growth and youth employment in Sub-Saharan Africa [28].

Agriculture will continue to be a major sector in employing citizens in poor countries. In low-income countries especially in sub Saharan countries, a decrease in the share of the workforce employed in agriculture is still accompanied by an increase in agricultural employment in absolute terms, as the population continues to grow fast and cultivated land (the "extensive margin") expands. Given high population growth, the agricultural workforce is projected to continue swelling in the foreseeable future before it starts to decline [11].

Agriculture in Africa is the predominant economic sector in most sub-Saharan African (SSA) countries, employing more than two-thirds of the labor force. Agriculture employs about $65 \%$ of the total work labor force in SSA for which $90 \%$ are youth [20]. It also serves all rural and some urban population as means of livelihood. Rural populations in sub-Saharan country are working in agriculture hence it remains the main occupation including in nations like Ethiopia [38].

Ethiopian agriculture is the largest sector which is approximately employing $85 \%$ of the country's population [50]. Agriculture, the mainstay of Ethiopian economy, directly supports about $85 \%$ of the population in terms of employment and livelihood contributes over $41 \%$ of the country's gross domestic product; and generates about $90 \%$ of export earnings. It is also an important sector in supplying food for the population and raw material for agro-based 
domestic industries and in generating surplus capital to speed up the country's overall socio-economic development [16]. Out of labor forces working in agriculture of Ethiopia, young people share about $50 \%$ [34].

\subsection{Statement of the Problem}

Even though it has potential to absorb large number of people, youth tend to stand away from the agricultural sector in Ethiopia [35]. It was also reported that large people; particularly young graduates from higher education are being away from agriculture due to many problems in country's side. These were: lack of good governance (nepotism, corruption, bias and discrimination), lack of social networks, divergence between skills and the labor market and low quality educational policy and system. It was found that, Nepotism and corruption (84.6\%), Ethnic and political bias and discrimination $(73.1 \%)$, lack of connections and social networks $(66.7 \%)$, mismatch between skills and the labor market $(60 \%)$, and misguided and low quality educational policy and system $(60 \%)$ are mentioned respectively as factors contributing for youth graduates unemployment. favoritism, corruption and bias and discrimination in different forms are indicated as factors responsible for youth graduates unemployment. More badly, participants seem to attribute their problems on to others[6].

Youth are influenced by many factors in order not to take part in agriculture and any related business in the country. Majority of them are not planning to take agriculture as their main livelihood with only $9 \%$ planning to work in the sector due to many challenging problems [9]. Agriculture is not attractive to youth due to high risks that may involve in it, intensive nature and low profitability of the sector [24]. Several factors that impede youths' involvement in agriculture include educational background, access to land, low agricultural productivity, seasonality of agricultural incomes, lack of public investment in agriculture and the low use of innovation and technology [39].

It is pointed out that low supply of bank credit to the agricultural sector, lack of agricultural insurance, lack of basic knowledge in agriculture and lack of access to agricultural inputs are the main constraints for participation of young people in agriculture which are also expected to be problem in micro and small agribusiness. Their awareness and commitment in the agriculture sector is left by youth many decades ago[1]. Women are holding smaller plots of land than men in many parts of the world indicating they are affected by land size they owned to engage in agriculture and produce more than or equal to men [23].

Additionally, this review will provide us other reasons for why youth are not participating in agri-business and what challenged them while working.

\subsection{Objective of the Review}

\subsubsection{General Objective}

The general objective of the review was assessing factors affecting youth participation in agri-business in Ethiopia.

\subsubsection{Specific Objectives}

The specific objectives of the review were:

1) To assess contribution of agribusiness in creating employment for youth in Ethiopia

2) To identify factors affecting youth participation in agribusiness in Ethiopia

3) To assess types of agribusiness in Ethiopia.

\subsection{Significance of the Review}

The importances of this review will serve as guidance for other researchers, whom may deal on similar topic. The review will also identify problems in the country and help the actors to focus on problems as one of the intervention for enhancing youth so they become input for the industry and use from the sector. Further it will provide information to who want to invest in Ethiopian agriculture.

\section{Literature Review}

This chapter presents the review regarding contextual definition of youth, Agribusiness, the role of agribusiness in employing youth and some problems affecting youth participation in agribusiness in Ethiopia.

\subsection{Theoretical Review}

\subsubsection{Youth}

There is no common definition of "youth" all over the world. Definition of youth perhaps changes with circumstances, especially with the changes in demographic, financial, economic and socio-cultural settings; however, the definition that uses 15-24 age cohort as youth fairly serves its statistical purposes for assessing the needs of the young people and providing guidelines for youth development. Youth is often understood as the period of adolescence during which young people make the transition from childhood to adulthood, become sexually and mentally mature and experience increasing social and economic autonomy or self dependency [4].

The United Nations define "youth" as those between 15 and 24 years of age [47]. The African Youth Charter on another hand defines youth as 15-35 years of age [2]. In Ethiopian context youth encompasses the age group between 14 to 29 years [37]. But, in this research, youth constitutes individuals who found between age limits of 18 and 33 years old, because youth with age 14-17 are too young to work in agribusiness.

\subsubsection{Youth Participation}

Participation is a fundamental right. It is one of the guiding principles of the Universal Declaration of Human Rights that has been reiterated in many other Conventions and Declarations. Youth participation is the involvement of young people in matters that affect them and an attempt to include them in the planning and decision making. Through active participation, young people are empowered to play a vital role in their own development as well as in that of their communities, helping them to learn vital life skills, develop 
knowledge on human rights and citizenship and to promote positive civic action. To participate effectively, young people must be given the proper tools, such as information, education about and access to their civil rights. Youth are very innovative class of community and they should be at the forefront of developing agriculture [24].

\subsubsection{Agribusiness Definition}

Agribusiness is a broad concept that covers input suppliers, agro-processors, traders, exporters and retailers. Agribusiness provides inputs to farmers and connects them to consumers through the financing, handling, processing, storage, transportation, marketing and distribution of agroindustry products [46].

In essence, agribusiness consists of all industries surrounding food production (manufacturing and processing industries), ultimate end-user, with marketing as the driving force behind all profitable activities. Agribusiness also deals with commodities that are of short shelf-life; hence, marketing plays a vital part in moving the inputs, products, and by-products to the different sectors and the consumers [40].

\subsection{Empirical Literature Review}

\subsubsection{Types of Agribusiness in Ethiopia}

Agriculture which includes crop production, animal husbandry, forestry, fisheries and apiculture remains by far the most important sector of the Ethiopia from which livestock constitute the largest component of the country's agricultural sector [26].

(i) Livestock production

Ethiopia is home to Africa's largest livestock population, and it is the continent's top livestock producer and exporter. In recent livestock population of Ethiopia is estimated to be about 52.1 million heads of cattle, 24.2 million sheep, 22.6 million goats and 44.9 million poultry [8].

From their long history, Ethiopians have constantly based on livestock for many purposes. Livestock in Ethiopia are extremely important to them as livestock provides a wide range of functions in society from social to subsistence purposes. It is an integral part of agriculture and the contribution of live animals and their products to the agricultural economy accounts for $40 \%$ [21].

(ii) Beef Cattle Production

Ethiopian farmers are known for their production of beef which cannot be denied. In both rural and urban areas, smallholder cattle fattening is emerging as an important source of employment and income. In rural Ethiopia, cattle fattening is based on locally available feed resources [42].

(iii) Dairy Production

In Africa, Ethiopia is usually reported to be empowered with the largest livestock population. According to the 2010 report of the Central Statistical Agency the cattle population was estimated at about 50.9 million [14].

In Ethiopia dairy production is one of the main agricultural businesses that are serving society. Ethiopian dairy production depends mainly on indigenous livestock genetic resources; more specifically on cattle, goats, camels and sheep. Cattle has the largest contribution $(81.2 \%)$ of the total national annual milk output, followed by goats (7.9\%), camels $(6.3 \%)$ and sheep for about $4.6 \%$ [13]. Indigenous breed of cows are generally considered as low milk providers with been major source of milk in Ethiopia and accounting for $98.59 \%$ of the total milk production in the country [17].

According to the report of central statistical agency $83 \%$ of all milk produced in Ethiopia comes from cattle with the remainder comes from goats and camels. It was also estimated that about 2.76 billion liters of cow milk produced by sedentary populations annually while camel milk is estimated at 16.2 million liters annually [12]. Dairy production is so much important for income generation and employing households where its development can contribute to poverty alleviation and nutritional improvement [3].

Dairy production has different potential of yield across the regions of Ethiopia. From the study done in Hawassa city the average daily milk yield at house hold level was estimated to be $13.3,51.5$ and 81.4 liters litter per house hold for the small, medium and large size farms, respectively with the overall average being 20.31 litters [29].

On other hand from the study done in Haramaya District, the overall average amount of milk produced by local cow breeds was 2.23 liters per day. About $2.4 \%$ of the participants have three milking cows, $30.9 \%$ own two milking cows, and $66.7 \%$ own only one milking cow per household [36].

(iv) Poultry Production

Poultry production is deeply embedded in Ethiopian society kept by all strata of society from the landless rural poor to the well off in the cities. In Ethiopia, the traditional back yard poultry production accounts for more than $90 \%$ of the national meat and egg output [18]. In most part of Ethiopia, village chicken represents a significant component of the rural household livelihood as a source of cash income for immediate household expenses and nutrition [27].

Chicken production is becoming an attractive business in Ethiopia with an introduction on new breeds. It was found that in the Western Ethiopia among chicken flocks; 82.94, 95.15 and $81.43 \%$ were indigenous breeds of Horro (highland), Bako-Tibe (lowland) and Leka-Dulecha (midaltitude), respectively; the remaining chicken breeds were commercial layers, broilers and exotic dual-purpose chickens or hybrids [19].

(v) Fruit and Vegetable Production

Ethiopia has a comparative advantage in a number of horticultural commodities due to its favorable climate, proximity to European and Middle Eastern markets and cheap labor. However, the production of horticultural crops is much less developed than the production of food grains in the country. On average more than 2,399,566 tons of vegetables and fruits are produced by public and private commercial farms, which are estimated to be less than $2 \%$ of the total crop production. According to recent information obtained from the Central Statistics Authority, the total area under fruits \& vegetables is about 12,576 hectares in 2011. Of the total land area under cultivation in the country during the 
same year, the area under fruits and vegetables is $0.11 \%$, which is insignificant as compared to food crops [22].

(vi) Cereal Crop Production

Ethiopia is an agrarian economy with a mainly rain fed agricultural system. The major grain crops grown in the country are teff, wheat, corn, barley, sorghum, and millet. Cereals are predominantly produced by small land holders and are consumed as food and the byproducts are fed to animals [43].

\subsubsection{Contribution of Agribusiness in Creating Employment Opportunity for Youth in Ethiopia}

Agriculture has been the main livelihood of many people in worldwide and investment in the agricultural sector has been found to be an effective means to lift group of people out of poverty [7]. Agriculture has accounted for more one third of total global employment by six years ago [32]. On average, $90 \%$ of rural young people are employed by their families or self employed in agriculture and household enterprises, while the same is true for $69 \%$ of urban youth. For those young people who are employed, on-farm employment constitutes the lion's share of jobs $(64 \%$ on average across the fifteen countries). The rural/urban divide is great here, not surprisingly: $76 \%$ of rural young people are employed in agriculture, while only $39 \%$ of urban counterparts are [10].

Around $80 \%$ of young workers in developing countries are engaged in informal employment (significant numbers of them on family farms and in rural areas). For most African countries, agriculture remains the largest employer of any sector in the economy [30].

Throughout Africa agribusiness projects have been creating employment opportunities for many young people [45]. It was reported that in Ethiopia 51.8\% participation rates in agricultural labor for the youth [32].

Ethiopia's economy is chiefly agricultural businesses, in which more than $80 \%$ of the country's population employed in this sector. The country's economy continues to rely heavily on agriculture, which accounts for $83.4 \%$ of employment [50]. Even there might be willing to inter and invest in agriculture, youth face barriers in entering agriculture such as insufficient access to knowledge, information and education and limited access to land, financial services, markets and engagement in policy dialogue [25]. Many young think/understand agriculture as of drudgery and the option of last choice; it is often not even considered by youth in the same vein as an actual career [48].

\subsubsection{Factors Affecting Youth Participation in Agribusiness}

There are a lot of challenges by which youth are inhibited from taking part in agribusiness across Ethiopia. From the study that was done in Gojjam, it is identified that lack of assets like money and skill, backwardness of agricultural tools, and attitudinal problems as the major challenges for youth engagement in agriculture [5].

It was indicated that both males and females (83.51\%) believed that they may face obstacles if they want to do farming as a means of livelihood. Land problem was the main obstacle mentioned by almost all respondents. From all informants surveyed in school youth $99.5 \%$ respondents have considered the land shortage as one of the major and most important problems that may impede youth engagement in agriculture. According to this finding more than half of the respondents' family land holding is one and below hectares of land $(63.3 \%)$ [5].

From the study in north shewa, Kuyyu district, Land availability was also found significant at $1 \%$ significance level with its marginal effect of 0.3575 in affecting youth participation in micro and small agribusinesses. The coefficient of land availability was positive which implies that land availability positively affects probability of youth participation in micro and small agribusiness. With its marginal effect it implies that land availability will increase the probability of youth participation in micro and small agribusiness by $35.75 \%$, keeping other variables constant [41].

Problem of agricultural input and asset problems were considered as the major obstacles by $84.6 \%$ and $81.4 \%$ of respondents respectively. One of the most important challenges related to asset was shortage of money to start agriculture. Youth who wants credit to start new business required to save at least twenty percent of money they want unless they couldn't access the credit. Thus, for youth who couldn't save the required amount of money, it is unthinkable to take credit. This was one of challenges for rural youth in the study area who decided to start farming. Moreover, agricultural inputs are another challenge in farming occupation. According to the same study input like fertilizer is too costly in the market. Its cost is increasing from year to year and becomes a common problem in agriculture [5].

The study also pointed out attitudinal problem as one of the major constraints in addition to others mentioned above. Here, attitudinal problem can be seen from two directions. The first is an attitude related to the interest of youth themselves to engage in agriculture. Thus, the issue of attitude here is the interest of individual themselves to engage in agriculture. The second is the attitudes of the general community towards the agricultural engagement of youth with some kind of formal education. Members of the community have no good words for those youth who engaged in agriculture after completing high school education and/or technical school [5].

Similar to this it was also found that attitude of communities to be among major problems affecting youth participation in agriculture from the study that have been done in Begi district of west Wollega. It was found that majority $(55.2 \%)$ of the respondents indicated that communities consider rural youth farmers as lazy workers who lost other job opportunities, whereas 128 (44.8\%) were considered rural youth as strong and good workers. Majority of rural youth participated in agriculture were considered as lazy workers who lost other chance of job. The families consider rural youth farmers as those who have no other job opportunities and do not have the chance of being other professional because the family wants their youth do government works and being reach through merchant 
activity. Because of familiese low attitude on agriculture rural youth participation in agriculture is getting low youth are aspire to other types of work. Rural youth recently reported that access to information, lack of credit and negative perceptions around farming are the leading reasons why rural young people are leaving small farming at such alarming rates [44].

From the finding in North shewa, career ambition was found significant at $1 \%$ significance level with marginal effect of -0.3227 in affecting youth participation in micro and small agribusiness. The coefficient of career ambition is negative and implies that career ambition negatively affects probability of youth participation in micro and small agribusiness. With its marginal effect it implies that for those who did not want to make agribusiness their profession, their probability of youth participation in micro and small agribusiness will decrease by $32.27 \%$ than their counterparts, keeping other variables constant. This means that youth who didn't have plan to make agribusiness their means of livelihood in future have a lower probability of participating in micro and small agribusiness than those who want to make agribusiness their means of livelihood in future [41].

Similarly, inaccessibility of technology or/and backwardness of agricultural tools, and attitudinal problems also considered as an obstacles by $63.8 \%$ and $61.2 \%$ of respondents respectively [5].

In Begi, district of west wollega the majority $(60.1 \%)$ of the respondents indicated that to a moderate extent access to credit influenced youth participation in agricultural activities, whereas $45(15.7 \%)$ indicated to a great extent, $25(8.7 \%)$ very great extent, $15(5.2 \%)$ not at all respectively influence rural youth participation in agriculture. The decision of youngsters or teenagers to engage in agriculture not only depends on the access to resources that person has both tangible and intangible assets but also depends on how a person behaves in comparison to his /her references groups (relative motive). The more an individual is concerned about relative income the more he is dissatisfied or motivated that may result in a change of livelihood decisions (such as increasing labor supply in agriculture and increase labor supply in non-farm, i.e. change occupation from farm to nonfarm employment), social unrest or migration [44].

Males and females are also not having equal probability of being employed in agriculture due to unequal accessibility of land to them. Female youths' land access before eight years was only $3 \%$ of all landholders in Ethiopia; even though the Ethiopian land laws provide equal land acquisition and use rights to male and female citizens. This implies degree to which even sex of youth affects participation of them in agribusiness. $75 \%$ of the household heads admit that none of their daughters will ever inherit land from them. In Damot Sore, where farm sizes are very small, only $6 \%$ of household heads have intention of bequeathing land to their daughters. The main source of access to land for young women must then be through marriage to a young man with land access, according to the report of Ethiopian tradition of women moving to the homestead of their husband upon marriage
[15].

\section{Conclusion and Recommendation}

\subsection{Conclusion}

Ethiopia is endowed with largest and varieties of natural resources in the world. Ethiopian Agriculture, the largest sector in Ethiopia remains the major economic activity with approximately employing $85 \%$ of the country's population with youth are sharing the half of population who are engaging in agribusiness. Agriculture which includes crop production, animal husbandry, forestry, fisheries and apiculture remains by far the most important sector of the Ethiopia from which livestock constitute the largest component of the country's agricultural sector. For these it is being very an important to the country and has wide range of business areas where citizens enjoy their life where it can absorb active labors more. Even though it plays important role in employing people, there are many problems or challenges affecting youth in agribusiness. Among those challenges limited access to land, inadequate access to financial services, gender or sex, backwardness of agricultural tools, and attitudinal problems are some of the challenges for youth involvement and advancement in agribusiness. The many hurdles in Ethiopian agriculture need intervention so as to increase youth participation in agriculture and bringing sustainable solution. Less number of rural youth participation in agriculture was found with being the results of social, economical and personal constraints. Therefore, providing improved credit system, aiding farmers and others to conserve soil, improving extension system and creating more awareness in changing backward attitudes of society and young people toward agriculture, introducing good varieties and animal species and bring in the new best and compatible tools are important to accelerate success in agribusiness. All these evidences call for an intervention in reducing the magnitude of challenges affecting youth engagement in agriculture.

\subsection{Recommendation}

The recommendations drawn in this paper are based on the evidence found from the review. The review has found a lot of challenges or hurdles hindering farmers/youth and reducing productivity of agricultural products. Land is the most important natural resource in the sense that it affects every aspect of a live on earth. This variable was found significant factor in affecting youth participation in agribusiness.

1) As land is concerned, government should take control over land use; government and nongovernmental sector should give more attention again in soil management work through funding and aiding farmers. For this local government should intensify agribusiness practices that can give more products per small plot of land.

2) For community are having back warded attitude toward young who engage in agriculture especially after 
college and further education, there should be an effort to change the attitude of the community concerning the mindset of a general belief that agriculture is only for uneducated and is only for young who are failed to pass exams.

3) Youth should be encouraged and get incentives when starting agriculture. Credit should be accessible to these youth without any difficult precondition.

4) It is necessary to change the traditional practice of agriculture by replacing it with the modern kind of agricultural technology that is appropriate for small scale farming.

\section{Acronyms and Abbreviation}

$\begin{array}{ll}\text { CSA } & \text { Central Statistical Agency } \\ \text { EIA } & \text { Ethiopian Investment Agency } \\ \text { FAO } & \text { Food and Agricultural Organization } \\ \text { ILO } & \text { International Labor Organization } \\ \text { MYSC } & \text { Ministry of Youth, Sports \& Culture } \\ \text { UNCCD } & \text { United Nations Convention to Combat Desertification } \\ \text { UNIDO } & \text { United Nations Industrial Development Organizations }\end{array}$

\section{Acknowledgements}

Above all, I thank the Almighty God for giving me health, peace and strength for the completion of this review.

\section{References}

[1] Adekunle, O. A., Adefalu, L. L., Oladipo, F. O., Adisa, R. S. and Fatoye, A. D., 2009. Constraints to youths' involvement in agricultural production in Kwara State, Nigeria. Journal of agricultural extension, 13 (1).

[2] African Union, 2006. African Youth Charter. Retrieved August 31, 2017, from African Union: http://www.africaunion.org/root/au/Documents/Treaties/Text/ African_Youth_Charter.pdf.

[3] Ahmed, M. A. M., S. Ehui and Y. Assefa, 2004. Dairy development in Ethiopia. International Food Policy Research Institute. Washington, U.S.A.

[4] Anyidoho, N. A., Kayuni, H., Ndungu, J., Leavy, J., Sall, M., Tadele, G. and Sumberg, J., 2012. Young people and policy narratives in sub-Saharan Africa.

[5] Aragaw Sergo, 2014. Aspirations of Rural Youth Towards Agriculture: The Case of Hulet Eju Enese Woreda, East Gojjam Zone. Addis Ababa, Ethiopia.

[6] Asmare, Y. and Mulatie, M., 2014. A Tale of Youth Graduates Unemployment. Global Journal of Human-Social Science: Arts \& Humanities - Psychology. Volume 14 (4).

[7] Bennell, P. 2010. Investing in the future: Creating opportunities for young rural people. Rome, Italy: IFAD.

[8] Berihu, H., Aleme, A. and Mulata, H., 2014. Constraints of Livestock Development in Eastern Zone of Tigray; the case of "GantaAfeshum Woreda" Northern Ethiopia. Agricultural Science, Engineering and Technology Research, 2 (1), pp. 1-
9.

[9] Bezu, S. and Holden, S., 2014. Are rural youth in Ethiopia abandoning agriculture?. World Development, 64, pp. 259272.

[10] Brooks, K., Zorya, S., Gautam, A. and Goyal, A., 2013. Agriculture as a Sector of Opportunity for Young People in Africa, The World Bank Sustainable Development Network Agriculture and Environmental Services Department. Policy Research Working paper, (6473).

[11] Christiansen, Luc, and Brooks, Karen. 2019. In Africa, More Not Fewer People Will Work in Agriculture. Consultative Group for International Agricultural Research.

[12] CSA, 2008. Agricultural Sample Survey. Report on livestock and livestock characteristics (private peasant holdings). Volume II. Addis Ababa, Ethiopia.

[13] CSA, 2009. Agricultural sample survey 2008/09. Report on livestock and livestock characteristics. Statistical bulletin 446 . Addis Ababa, Ethiopia.

[14] CSA, 2010. Agricultural Sample Survey: Livestock, Poultry and Beehives population (private peasant holdings). Federal Democratic Republic of Ethiopia, Central Statistical Authority (CSA), Addis Ababa, Ethiopia.

[15] CSA, 2012. Agricultural sample survey 2011/2012, Volume IV: Report on Land Utilization. Addis Ababa, Ethiopia: Central Statistical Agency.

[16] CSA, 2014. Ethiopia Mini Demographic and Health Survey. Addis Ababa, Ethiopia.

[17] CSA, 2017. Central Statistics Agency of Ethiopia.

[18] Dana, N., Duguma, R., Teklewold, H. and Aliye, S., 2006. Transforming village poultry systems into small agro-business ventures: a partnership model for the transfer of livestock technologies in Ethiopia. Livestock Research for Rural Development, 18.

[19] Demissu Hundie1*, Gebeyehu Goshu2, Berhan Tamir2 and Gemeda Duguma, 2019. Assessment on rural poultry production and marketing system of Horro chicken ecotypes in Western Ethiopia. Journal of Agricultural Extension and Rural Development, Vol. 11 (12), pp. 248-259.

[20] Devèze, J. C., International Bank for Reconstruction and Development and Paris Agence Française de Développement, 2011. Challenges for African agriculture. World Bank.

[21] Duguma, B., Tegegne, A. and Hegde, B. P., 2012. Smallholder livestock production system in Dandi district, Oromia Regional State, central Ethiopia. Read and write, 20, pp. 25-6.

[22] Ethiopian Investment Agency, 2012. Investment Opportunities Profile for production of fruits and vegetables in Ethiopia; Addis Ababa.

[23] FAO, 2011. The State of Food and Agriculture 2010-11: women in agriculture. Closing the gender gap for development. Rome.

[24] FAO, 2012. Message from the Food and Agriculture Organization of the United Nations on the occasion of the $17^{\text {th }}$ International Day of Co-operatives "Youth, the future of cooperative enterprise" Unpublished. 
[25] FAO, 2014. Youth and agriculture: Key challenges and concrete solutions.

[26] Gashaw, T., Asresie, A. and Haylom, M., 2014. Climate change and livestock production in Ethiopia. Adv. Life Sci. Tech, 22, pp. 38-42.

[27] Habte, M., Ameha, N. and Demeke, S., 2013. Production performance of local and exotic breeds of chicken at rural household level in Nole Kabba Woreda, Western Wollega, Ethiopia. African Journal of Agricultural Research, 8 (11), pp. 1014-1021.

[28] Haggblade, S. And Hazell, P. B. R. (2010). Successes in African Agriculture: Lessons for the Future. IFPRI Issue Brief, 63. Washington: IFPRI.

[29] Haile Welearegay, Zelalem Yilma and Yosef Tekle-Giorgis, 2012. Challenges and opportunities of milk production under different urban dairy farm sizes in Hawassa City, Southern Ethiopia, African Journal of Agricultural Research Vol. 7 (26), pp. 3860-3866.

[30] ILO, 2013. Global employment trends for youth 2013: A generation at risk. Geneva: International Labor Office.

[31] ILO, 2014 (a). Decent Work Country Program 2014-15: Ethiopia / International Labor Organization, ILO Country Office for Ethiopia and Somalia. - Addis Ababa.

[32] ILO, 2014 (b). Global employment trends: Risk of a jobless recovery? Geneva: International Labour Organization.

[33] Koira, A. K., 2014. Agribusiness in sub-Saharan Africa: Pathways for developing innovative programs for youth and the rural poor. Working Paper (Toronto, The MasterCard Foundation).

[34] Maïga, E., Christiaensen, L. and Palacios-Lopez, A., 2015, December. Are Youth Exiting Agriculture en Masse. In STAARS Conference in Addis Ababa.

[35] Mangal, H., 2009. Best Practices for Youth in Agriculture: The Barbados, Grenada and Saint Lucia Experience. Final report.

[36] Mitiku Eshetu, Mekdes Seyoum and Yesihak Yusuf Mummed, 2019. Milk production, marketing practices and qualities along milk supply chains of Haramaya District, Ethiopia. African Journal of Agricultural Research, Vol. 14 (35), pp. 1990-2005.

[37] MYSC, 2004. National Youth Policy. $100^{\text {th }}$ FDRE Council of Ministers' Meeting, Addis Ababa.

[38] Naamwintome, B. A. and Bagson, E., 2013. Youth in agriculture: Prospects and challenges in the Sissala area of Ghana. Net Journal of Agricultural Science, 1 (2), pp. 60-68.

[39] Njenga, P., Mugo, F. \& R. Opiyo, 2012. "Youth and Women Empowerment through Agriculture in Kenya", Main Report Voluntary Services- Overseas.

[40] Olokundun, A. M., Falola, H. O. and Ibidunni, O. S., 2014. Agro Business as a Remedy for Youth Unemployment towards the Acheivement of Sustainable Development in Nigeria: Comparative Perspectives from the Kwara State Agro Business Economy. Journal of Economics and Sustainable Development, 5 (3), pp. 46-57.

[41] Taddesse Moreda Tura, Panchugopal Biswas, Guta Regasa, 2017. Factors Affecting Youth Participation in Micro and Small Agribusiness: The Case Of Kuyyu District, North Shewa Zone Of Oromia Regional State, Ethiopia. International Journal of Research in Economics and Social Sciences (IJRESS), Vol. 7 Issue 11.

[42] Taye, T. and Lemma, H., 2009. Traditional Backyard Cattle Fattening in Wolayta: Systems of Operation and the Routine Husbandry Practices. Ethiopian Journal of Animal Production, 9 (1), p. 39.

[43] Tefera, A., 2013. Ethiopia. Grain and feed annual. Rep. no. ET-1301. Np: Global Agricultural Information Network.

[44] Tizazu Obsa Likasa (2019). "Rural Youth Participation in Agriculture in Begi district of West Wollega Zone of Oromia regional state, Ethiopia". IOSR Journal Of Humanities And Social Science (IOSR-JHSS) Volume 24

[45] UNCCD, 2015. Sustainable Land Management and Employment Opportunities. Can SLM create employment opportunities? K. ARAPNAKOVA, Namibia.

[46] UNIDO, 2011. Agribusiness for Africa's Prosperity, Printed in Austria, May 2011.

[47] United Nations, 2011. Frequently Asked Questions. Retrieved August 31, 2017, from Youth: Social Policy and Development Division: http://social.un.org/index/Youth/FAQs.aspx

[48] White, B., 2012. Agriculture and the generation problem: rural youth, employment and the future of farming. IDS Bulletin, 43 (6), pp. 9-19.

[49] World Bank, 2007. Africa Development Indicators. Washington: World Bank.

[50] World Bank, 2012. World Development Report 2013: Jobs. Washington DC: World Bank. 